\title{
Nuevas lógicas y sentidos de la práctica de la Práctica profesional
}

\author{
Alegre, Luciana G. ${ }^{1}$, Pradolini, Viviana A. ${ }^{2}$, Testoni, Cecilia R. ${ }^{3}$
}

\section{Resumen}

Desde el espacio curricular de formación de grado, la Práctica Preprofesional de Terapia Ocupacional de la Universidad Nacional del Litoral, retomamos y profundizamos algunas cuestiones planteadas en torno al supuesto de la práctica como productora de contextos.

Problematizamos sobre los modelos de pensamiento disciplinares que resultan insuficientes en la práctica profesional contextualizada. Interpelamos y reflexionamos desde y sobre la práctica, entre la mirada teórica tradicional centrada en la función- disfunción del individuo y el surgimiento del paradigma emergente en la profesión, enfocado en la promoción de salud y derechos en los grupos y poblaciones, redimensionando la noción de ocupación colectiva.

Intentando comprender los modos de vida de las poblaciones y la producción del conocimiento en la posmodernidad que nos atraviesa, tomamos los aportes de Souza Santos para proponer niveles de análisis y teorización sobre la práctica profesional como productora de contextos.

La discusión nos aproxima a las siguientes reflexiones: a- reconocer como objeto de la disciplina al sujeto comprometido en sus ocupaciones, b- re significar las categorías de conocimiento y niveles de teorización de la práctica, c- estar implicados en la realidad de los contextos. Las mismas se plasmaron en la reasignación de los perfiles de centros de prácticas y construcción de nuevos escenarios, no convencionales, donde poner en juego otras lógicas y sentidos desde la perspectiva de promoción de la salud.

Palabras clave: terapia ocupacional, práctica profesional, contexto, paradigmas

\footnotetext{
${ }^{1}$ Escuela Superior de Sanidad. Facultad de Bioquímica y Ciencias Biológicas, Universidad Nacional del Litoral. Santa Fe, Argentina. lucianalegre@yahoo.com.ar

2 Escuela Superior de Sanidad. Facultad de Bioquímica y Ciencias Biológicas, Universidad Nacional del Litoral. Santa Fe, Argentina. vivipradolini@gmail.com

${ }^{3}$ Escuela Superior de Sanidad. Facultad de Bioquímica y Ciencias Biológicas, Universidad Nacional del Litoral. Santa Fe, Argentina. testonicecilia@gmail.com
} 


\section{Summary}

From the Pre-professional Practice area of Occupational Therapy of the Universidad Nacional del Litoral, we return and deepen some questions raised about the course of the practice as a producer of contexts.

Problematize on disciplinary thinking patterns which are insufficient in professional practice context. We reflect from and practice, between the traditional focus view centered functiondisfuntion of the individual and the rise of emerging paradigm in the profession, focused on promoting health and rights of groups and populations, resizing the notion of collective occupation.

Trying to understand the ways of life of the people and the production of knowledge in postmodernity through us, we take the contributions of Souza Santos to propose levels of analysis and theorizing on professional practice as a producer of contexts. The discussion brings us closer to the following reflections : a- recognize as an object of discipline the subject committed to their occupations, b- re mean the categories of knowledge and levels of theorizing practice, $\mathrm{c}-$ be involved in the reality of the contexts. They were expressed in the reallocation of practice profiles centers and construction of new scenarios, unconventional, to put into play other logics and meanings from the perspective of health promotion.

Keywords: occupational therapy, professional practice, context, paradigms 